\title{
Anti-Bacterial Activity of Cinnamon Oil on Oral Pathogens
}

\author{
Zamirah Zainal-Abidin ${ }^{1, *}$, Shahida Mohd-Said ${ }^{1,2}$, Fadzilah Adibah Abdul Majid ${ }^{3}$, Wan Aida Wan \\ Mustapha $^{4}$ and Ibrahim Jantan ${ }^{2}$
}

${ }^{I}$ Faculty of Dentistry, Universiti Kebangsaan Malaysia, Kuala Lumpur

${ }^{2}$ Faculty of Pharmacy, Universiti Kebangsaan Malaysia, Kuala Lumpur

${ }^{3}$ Faculty of Chemical Engineering, Universiti Teknologi Malaysia, Skudai, Johor

${ }^{4}$ Faculty of Science and Technology, Universiti Kebangsaan Malaysia, Bangi, Selangor

\begin{abstract}
The study aimed to determine the in-vitro anti-bacterial effect of cinnamon (Cinnamomum zeylanicum Blume) oil on pathogenic oral bacteria. Essential oil from cinnamon tree bark was extracted using steam distillation technique and analysed using gas chromatography (GC) and gas chromatography - mass spectrometry (GC-MS). Broth microdilution test was used to determine the Minimal Inhibitory Concentration (MIC) of oil against major oral pathogens in caries and periodontal diseases viz. Streptococcus mutans, S. mitis, S. salivarius, Aggregatibacter actinomycetemcomitans, Porphyromonas gingivalis and Fusobacterium nucleatum. Bacterial cell membrane modification following exposure to the oil was observed using scanning electron microscopy (SEM). Through the GC/GC-MS analysis, cinnamaldehyde was identified as the major component of cinnamon oil (82.5\% in relative amount). Both cinnamon oil and cinnamaldehyde showed antibacterial activity against the tested bacteria (MIC $0.21-0.63 \mathrm{mg} / \mathrm{mL}$ and $0.8-0.15 \mathrm{mg} / \mathrm{mL}$ respectively). Cell membrane changes were observed following $2 \mathrm{~h}$ exposure to the oil. This finding suggests cinnamon bark oil as a potential therapeutic agent in preventing bacterial-related oral diseases.
\end{abstract}

Keywords: Antibacterial, Periodontal, Cinnamomum zeylanicum.

\section{INTRODUCTION}

Dental caries (tooth decay) and periodontal disease (gum disease) are the most common oral diseases worldwide [1]. One of the most important contributing factors for the progression of these oral diseases is the biodiversity and complex nature of the dental plaque; it acts as a biological film where various bacterial species interact and may form a protective barrier against anti-microbial agents, resulting in resistance to common antibacterial agents used in clinical dentistry [2]. Among the strongly disease-associated oral bacteria are the anaerobic Gram-negative species of Porphyromonas gingivalis, Treponema denticola and Enterococcus faecalis, as well as mutans streptococci [3, 4]. These bacterial species are most virulent in dental plaque community and are resistant to treatment modalities, with a number of them being difficult to cultivate when tested in invitro environment [5]. Thus, many recent research are increasing being carried out to develop effective antibacterial agents against them.

Common domestic spices and herbs including betel leaves, black pepper, cloves and cinnamon have been used traditionally as remedies for oral conditions like toothache and gum swelling. More recently, scientific research has also

*Address correspondence to this author at the Faculty of Dentistry, Universiti Kebangsaan Malaysia, Kuala Lumpur; Tel: +603-92897122; Fax: +603-26982944; E-mail: zza 30@yahoo.com shown potential antibacterial properties of extracts from these herbs [6-9]. Application of the development of such bioassays in clinical science may offer beneficial knowledge and approach to management of oral disease. Several studies have been done to determine the usage of herbal essential oils in managing dental diseases $[7,10]$. Among the plants studied is Cinnamomum zeylanicum Blume (cinnamon) $[8$, 11]. Cinnamon is locally grown and available and has been used safely in traditional medicine for decades. Although antimicrobial properties of cinnamon oil have been reported recently, scientific evidence on the action of cinnamon oil on pathogenic oral bacteria, particularly pathogens related to periodontal disease, is still scarce. Thus, this study aimed to identify and determine the in-vitro anti-bacterial effect of cinnamon (Cinnamomum zeylanicum Blume) bark oil on selected pathogenic oral bacteria.

\section{MATERIALS AND METHODS}

\section{Essential Oil Extraction}

Dried bark of Cinnamomum zeylanicum Blume were purchased from a local nursery. Approximately $150 \mathrm{~g}$ of coarsely grounded herbal material were used for extraction of essential oil using the hydro-distillation technique for 8 hours. The oily layers were separated and dried using anhydrous magnesium sulphate, purified through a modified wool filter and finally stored at $4{ }^{\circ} \mathrm{C}$ in air-tight bottles until 
use. Moisture content was measured separately using the Dean's stalk and done in triplicates [12].

\section{Gas Chromatography (GC) and Gas Chromatography- Mass Spectrometry (GC-MS)}

A Shimadzu GC2000 gas chromatography equipped with column DB-5 ( $1 \mu \mathrm{m}$ thickness, $30 \mathrm{~m}$ length, $0.25 \mathrm{~mm}$ i.d) was used for the analysis of oils. Injector and flame ionization detector (FID) temperature were maintained at $250^{\circ} \mathrm{C}$. The samples were dissolved in ethyl acetate and 0.1 $\mu \mathrm{L}$ of each samples were injected in split mode. Nitrogen was the carrier gas used with a flow rate of $1.0 \mathrm{~mL} / \mathrm{min}$. Initial temperature of the oven was programmed at $75^{\circ} \mathrm{C}$ for the initial $10 \mathrm{~min}$, then $3^{\circ} \mathrm{C} / \mathrm{min}$ to $230^{\circ} \mathrm{C}$ for $5 \mathrm{~min}$. Total program time was $73.33 \mathrm{~min}$ (modified from [13]).

Essential oils were 'spiked' using the combined chromatography technique [14]. Using the same protocol as before, each essential oil sample was injected with a mixture of standard hydrocarbon series of $\mathrm{C}_{8}-\mathrm{C}_{21}$. Location of each carbon series were identified based on the retention time of carbon series run in the chromatogram earlier.

Analysis of the essential oils were also examined using a Shimadzu QP5050A GC-MS System with column HP-5MS and held at stationary phase under controlled condition; initial temperature at $75^{\circ} \mathrm{C}$ for $5 \mathrm{~min}$, then maintained at $250^{\circ} \mathrm{C}$ for $10 \mathrm{~min}$. Helium was used as the carrier gas at 1.2 $\mathrm{mL} / \mathrm{min}$ air flow. Injector and detector temperature were maintained at $240-280^{\circ} \mathrm{C}$.

\section{Identification of Oil Constituents}

All components of the essential oil were identified by comparing their retention indices (RI) based on Kováts index calculation using homologous series of alkanes $\mathrm{C}_{8}-\mathrm{C}_{21}[14$, 15] and GC-MS database library.

\section{Bacterial Culture and Growth Maintenance}

Oral bacteria used in the study were Aggregatibacter (Actinobacillus) actinomycetemcomitans (ATCC 29522), Fusobacterium nucleatum (ATCC 25586), Porphyromonas gingivalis (ATCC 33277), Streptococcus salivarius (ATCC 13419), Streptococcus mitis (ATCC 6249) and Streptococcus mutans (ATCC 25175). All the strains were purchased from the American Type Culture Collection (ATCC).

A. actinomycetemcomitans was cultured in tryptic soy broth-vancomycin (TSBV), $P$. gingivalis and $F$. nucleatum were cultured on trypticase yeast agar enriched with $5 \%$ fresh bovine blood, haemin $(5 \mu \mathrm{g} / \mathrm{mL})$ and Vitamin $\mathrm{K}(0.5$ $\mu \mathrm{g} / \mathrm{mL}$ ) (ETY). Streptococci spp. were cultured and maintained on mitis-salivarius-bacitracin-sucrose (MSA) agar. A. actinomycetemcomitans, $P$. gingivalis and $F$. nucleatum were grown in anaerobic environment with $5 \%$ $\mathrm{H}_{2}, 5 \% \mathrm{CO}_{2}, 90 \% \mathrm{~N}_{2}$ at $37^{\circ} \mathrm{C}$ for 24 to 48 hours while Streptococci spp. were grown aerobically throughout the study.

\section{Broth Microdilution Technique}

The antibacterial assay techniques were based on broth microdilution techniques in accordance to standards recommended by laboratory guidelines for aerobic bacteria
[16] and anaerobic bacteria [17] where bacteria were grown and tested in suspension broth. All bacteria were initially cultured in their respective test broth i.e. Streptococci spp. and $A$. actinomycetemcomitans in BHI broth, and $P$. gingivalis and $F$. nucleatum in ETY broth.

\section{Minimal Inhibitory Concentration}

Two-fold serial dilutions of oil samples ranging from $10.0-0.08 \mu \mathrm{L} / \mathrm{mL}(\mathrm{v} / \mathrm{v})$ were prepared in dimethylsulfoxide (DMSO). Each series of mixtures were mixed in BHI and ETY broth separately, and dispensed into a 96-well microtitre plate $(100 \mu \mathrm{L} /$ well). Subsequently, suspensions of the $24-48 \mathrm{~h}$ cultured bacteria in BHI and ETY broths were adjusted to $0.5 \mathrm{McF}$ arland turbidity standard (approximately $1.5 \times 10^{8} \mathrm{cfu} / \mathrm{mL}$ ). Each bacterial suspension were dispensed into the wells to give a range of final concentrations of samples of $5.0,2.5,1.25,0.63,0.31,0.16,0.08,0.04 \mu \mathrm{L} / \mathrm{mL}$. Triplicate samples were performed for each test concentration in addition to a blank sample (without bacterial suspension).

After $48 \mathrm{~h}$ incubation, the antibacterial activity was recorded using visual confirmation and reading of absorbance using a plate reader (Varioskan, Fischer Scientific) at $590 \mathrm{~nm}$ wavelength. The lowest concentrations of series which inhibited visible growth of bacteria, were recorded as the Minimum Inhibitory Concentration (MIC) for each extract. Tests were repeated three times and the means of MIC values of each test were recorded.

\section{Antibacterial Activity of Volatile Constituents of the Essential Oils}

Based from the gas chromatography analysis, main constituents of the essential oils were identified and used as the test agents. Final concentrations of standards used were $1600-12.5 \mu \mathrm{L} / \mathrm{mL}(\mathrm{v} / \mathrm{v})$. Similar methods were employed as above to prepare the sample mixtures, bacterial suspensions and reaction wells for determination of MIC values.

\section{Scanning Electron Microscopy}

The bacterial membrane changes was determined by scanning electron microscopy (SEM), modified from [18] and standard operating protocol adapted by SEM Unit, Universiti Kebangsaan Malaysia Medical Centre (PPUKM). Overnight cultured bacteria in suspension broths were exposed to cinnamon oil prepared in DMSO at $2.5 \mathrm{mg} / \mathrm{mL}$ $(\mathrm{w} / \mathrm{v})$ and incubated either aerobically or anaerobically for $2 \mathrm{~h}$ at $37^{\circ} \mathrm{C}$. Cultures without presence of cinnamon oil were used as controls. The bacteria cells were then collected through centrifugation at $1000 \mathrm{rpm}$ for $1 \mathrm{~min}$, rinsed twice in PBS ( $\mathrm{pH} 7.2$ ) and fixed in 3\% glutaraldehyde (grade I) between $30 \mathrm{~min}$ to $1 \mathrm{~h}$ at room temperature. The cells were washed with PBS three times for 10 min each wash and left to sit in $1 \%$ osmium tetroxide $\left(\mathrm{OsO}_{4}\right)$ for $30 \mathrm{~min}$ to facilitate observation in appropriate contrast during viewing later. The cells were again washed with PBS for $10 \mathrm{~min}$, followed by distilled water twice for $10 \mathrm{~min}$ each. Subsequently, cells were dehydrated in graded ethanol solution at 30\%, 50\%, $70 \%$ and $90 \%$ for 10 min each step. Lastly, the cells were 
Table 1. Identified Chemical Constituents of C. zeylanicum Bark Oil

\begin{tabular}{|c|c|c|c|}
\hline Constituents & $\%$ Amount & RI & Identification Methods \\
\hline$\alpha$-pinene & 1.4 & 941 & $\mathrm{a}, \mathrm{b}$ \\
\hline 1,8 -cineole & 0.5 & 1034 & $a, b$ \\
\hline (Z)- $\beta$-ocimene & 1.3 & 1039 & $a, b$ \\
\hline Borneol & 0.9 & 1168 & $\mathrm{a}, \mathrm{b}$ \\
\hline Cinnamaldehyde $<$ E- $>$ & 82.5 & 1288 & $\mathrm{a}, \mathrm{b}$ \\
\hline Eugenol & 0.5 & 1363 & $\mathrm{a}, \mathrm{b}$ \\
\hline Isoeugenol $<(E)->$ & 0.5 & 1450 & $\mathrm{a}, \mathrm{b}$ \\
\hline
\end{tabular}

RI (retention index) and percentages of yield (\%) were calculated based on the concentrations obtained on column DB5; a $=$ retention index based on calculation of Kováts index ${ }^{8}$; $\mathrm{b}$ $=$ Gas chromatography-mass spectrometry

Table 2. Minimum Inhibitory Concentrations (MIC) of Cinnamon Oil and Major Volatile Compounds against Oral Bacteria

\begin{tabular}{|c|c|c|c|}
\hline & C. zeylanicum Oil & Eugenol & Cinnamaldehyde \\
\hline A. actinomycetemcomitans & 0.21 & 0.15 & 0.23 \\
\hline F. nucleatum & 0.42 & 0.80 & 0.30 \\
\hline P. gingivalis & 0.63 & 0.80 & 0.30 \\
\hline S. salivarius & 0.31 & 0.40 & 0.40 \\
\hline S. mitis & 0.52 & 0.40 & 0.40 \\
\hline S. mutans & 0.63 & 0.40 & 0.40 \\
\hline
\end{tabular}

MIC values indicated as means, in $\mu 1 / \mathrm{mL}$ or $\mu \mathrm{g} / \mathrm{mL}$. Tested concentrations ranged between 0.04-5.0 $\mu \mathrm{L} / \mathrm{mL}$ w/v (essential oils) and $12.5-1600 \mu \mathrm{g} / \mathrm{mL}$ w/v (standards).

dehydrated twice in absolute ethanol concentration for 10 min intervals and cleaned with acetone twice for $15 \mathrm{~min}$. The cells were finally observed under scanning electron microscope (Quanta200, FEI, Netherlands) at 20,000x magnification.

\section{RESULTS AND DISCUSSION}

\section{Chemical Composition of the Essential Oil}

The evaluation on the chemical composition of essential oil of C. zeylanicum bark was carried out using GC/GC-MS. In the essential oil, seven major constituents were identified, representing $87.6 \%$ of the total oil (Table 1). The major compound in the $C$. zeylanicum bark oil was cinnamaldehyde $(82.5 \%)$, followed by $\alpha$-pinene $(1.4 \%)$ and cis-beta ocimene $(1.3 \%)$. The rest of the components were present in amounts less than $1 \%$. The cinnamaldehyde being the major component of cinnamon bark oil is in agreement with those previously reported, i.e. $44.2 \%$ [12] and 68.95\% [8].

C. zeylanicum oil showed strong growth inhibition activity against all the pathogenic oral bacteria tested, with MIC mean values between $0.21 \pm 0.04$ to $0.63 \pm 0.23 \mu \mathrm{L} / \mathrm{mL}$ $(\mathrm{v} / \mathrm{v})$ and no preference over the type of bacteria tested
(Table 2). From the oil analysis, two major volatile standards i.e cinnamaldehyde (Fluka 96350) and eugenol (Fluka 46100) were selected and tested on the bacterial species. Both cinnamaldehyde and eugenol standards showed profound activity against both Streptococci spp. and Gram negative anaerobes (Table 2). Active concentration for both compounds ranged between $0.15-0.8 \mu \mathrm{g} / \mathrm{mL}(\mathrm{w} / \mathrm{v})$. The findings on the activity of cinnamon bark oil against both Gram positive and Gram negative bacteria in this study is quite similar with a previous report [8].

\section{Morphological Changes Following Exposure to Cinna- mon Oil}

The changes on the bacterial cell surface following $2 \mathrm{~h}$ exposure to the cinnamon bark oil $(2.5 \mathrm{mg} / \mathrm{mL})$ were compared with the unexposed bacterial cells (Fig. 1). There is increased translucency of the bacterial cells of $S$. mutans, $P$. gingivalis, and $F$. nucleatum. These findings suggest that exposure to cinnamon bark oil may have induced changes to the surface membrane of the tested bacteria. However, the changes observed differ from one bacteria species to another, suggesting the mechanism on how cinnamon bark oil induced the changes to the surface membrane may differ according to the bacteria species tested. 

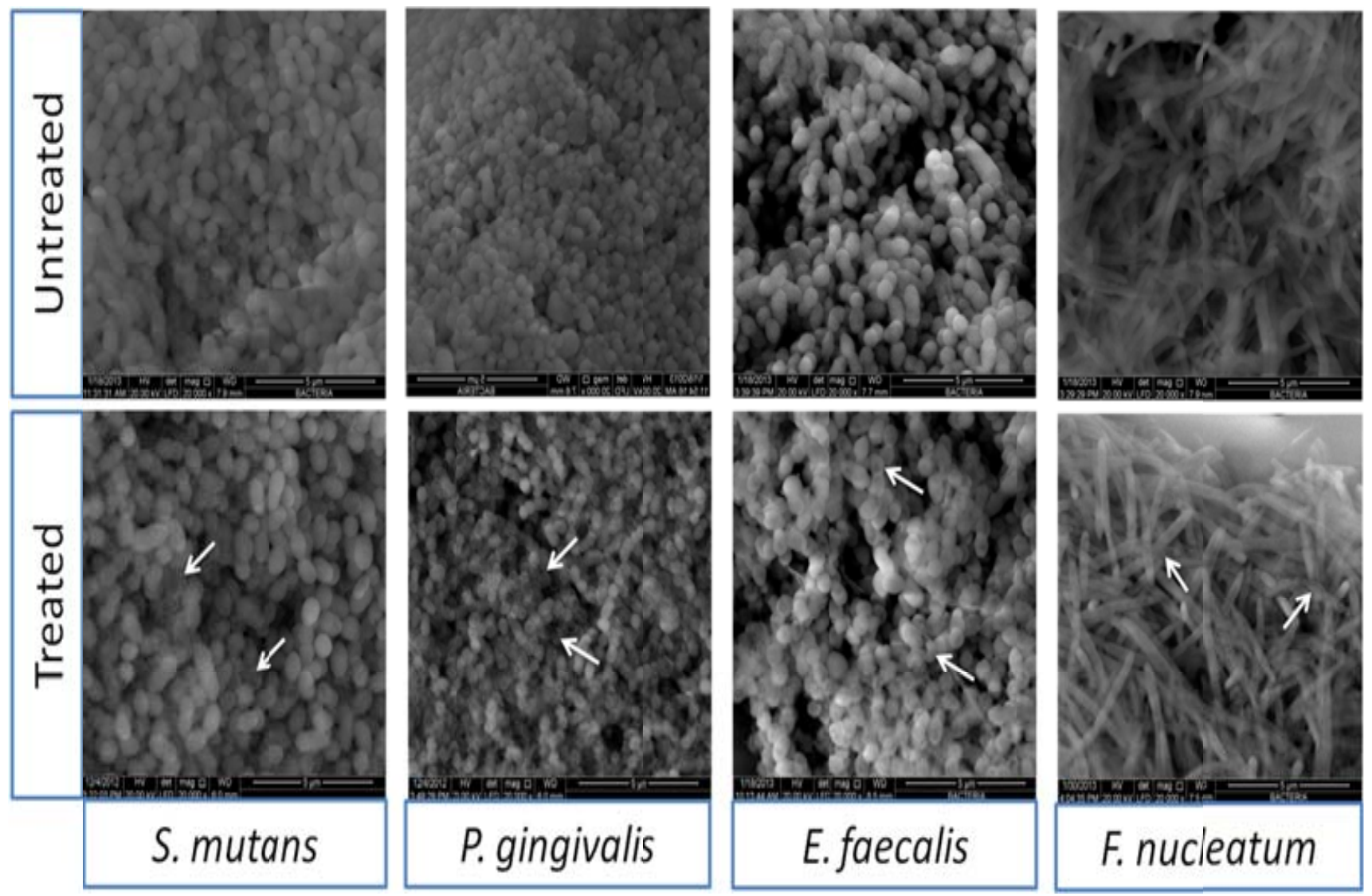

Fig. (1). SEM images of the oral bacteria untreated cells and after treatment with $2.5 \mathrm{mg} / \mathrm{mL}$ cinnamon oil prepared in DMSO for $2 \mathrm{~h}$. The changes are indicated by the white arrows.

\section{CONCLUSION}

The findings reported in this study suggest that cinnamon bark oil and its constituents have a potential to be developed as a therapeutic agent in preventing bacterial-related oral diseases. Further in-vivo studies on the mechanisms of the antibacterial activities of cinnamon bark oil are warranted.

\section{CONFLICT OF INTEREST}

The authors confirm that this article content has no conflicts of interest.

\section{ACKNOWLEDGEMENT}

This project was supported by Universiti Kebangsaan Malaysia's Research University Grant (code UKM-GUPTKP-08-22-076). The authors wished to thank staffs at the SEM Unit, Universiti Kebangsaan Malaysia Medical Centre (PPUKM) for their assistance in the SEM study.

\section{REFERENCES}

[1] Petersen, PE. The World Oral Health Report 2003: continuous improvement of oral health in the 21st century: The approach of the WHO Global Oral Health Programme. Commun Dent Oral Epidemiol 2003; 31 (Suppl 1): 3-23.

[2] Wilson M. Susceptibility of oral bacterial biofilms to antimicrobial agents. J Med Microbiol 1996; 44: 79-87.
[3] Holt SC, Ebersole JL. Porphyromonas gingivalis, Treponema denticola, and Tannerella forsythia: the "red complex", a prototype polybacterial pathogenic consortium in periodontitis. Periodontology 2000 2005; 38: 72-122.

[4] Loesche W. Dental caries and periodontitis: contrasting two infections that have medical implications. Infect Dis Clin North Am 2007; 21(2): 471-502.

[5] Smalley JW. Pathogenic mechanisms in periodontal disease. Adv Dent Res 1994; 8: 320-8.

[6] Samy RP, Gopalakhrisnakone P. Therapeutic potential of plants as antimicrobial for drug discovery. Evid Based Compl Alter. Med 2008; eCAM; 1-12.

[7] Palombo EA. Traditional medicine plants extracts and natural products with activity against oral bacteria: Potential application in the prevention and treatment of oral disease. Evid Based Compl Alter Med 2009; 10: 1-15.

[8] Unlu M, Erge E, Unlu GV, Zeytinoglu HS, Vural. Composition, antimicrobial activity and in vitro cytotoxicity of essential oil from Cinnamomum zeylanicum Blume (Lauraceae). Food Chem Toxicol 2010; 48: 3274-80.

[9] Cai L, Wu CD. Compounds from Syzygium aromaticum possessing growth inhibitory activity against oral pathogens. J Nat Prod 1996; 59: $987-90$.

[10] Takarada K, Kimizuka R, Takahashi, N, Hinma K, Okuda K, Kato T. A Comparison of the antibacterial efficiencies of essential oils against oral pathogens. Oral Microbiol Immunol 2004; 19: 61-4.

[11] Lalit Kumar DLKC, Arun BAJ, Sheeba SS, Hemant HS, Kumar, CDMC, Pooja Adwait PAK. Antimicrobial activity of commercially available essential oils against Streptococcus mutans. J Contemp Dent Pract 2012; 13: 71-74.

[12] Jantan IB, Moharam KBA, Santhanam J, \& Jamal JA. Correlation between chemical composition and antifungal activity of the essential oils of eight Cinnamomum Species. Pharm Biol 2008; 46(6): 406-412. 
[13] Ahmad F, Moharm BA, Jantan I. A comparative study of the constituents of the essential oils of Goniothalamus tapis Miq. and G. tapisoides mat salleh from borneo. J Essential Oil Res 2010; 22(6): 499-502.

[14] Adams RP. Identification of Essential Oil Components by Gas Chromatography - Mass Spectrometry (p. 804). Allured Pub Corp.; 2007.

[15] Kováts, E. Gas chromatographic characterization of organic substances in the retention index system. Adv Chromatogr, 1965 (1 FG - 0), 229-247.
[16] Clinical and Laboratory Standards Institute. M07-A9 Methods for Dilution Antimicrobial Susceptibility Tests for Bacteria That Grow Aerobically; Approved Standard - Ninth ed., (2012a), pp. 32(2).

[17] Clinical and Laboratory Standards Institute. M11-A8 Methods for Antimicrobial Susceptibility Testing of Anaerobic Bacteria; Approved Standard - $8^{\text {th }}$ ed., (2012b), pp. 32(5).

[18] Alviano WS, Mendonça-Filho RR, Alviano DS, et al. Antimicrobial activity of Croton cajucara Benth linalool-rich essential oil on artificial biofilms and planktonic microorganisms. Oral Microbiol Immunol 2005; 20: 101-5.

(C) Zainal-Abidin et al.; Licensee Bentham Open.

This is an open access article licensed under the terms of the Creative Commons Attribution Non-Commercial License (http://creativecommons.org/licenses/by$\mathrm{nc} / 3.0 /$ ), which permits unrestricted, non-commercial use, distribution and reproduction in any medium, provided the work is properly cited. 